\title{
Miguel de Cervantes Saavedra, Alonso Quijano, Don Quixote de la Mancha and medicine
}

\author{
Miguel de Cervantes Saavedra, Alonso Quijano, Don Quijote de la Mancha y la medicina
}

\author{
Raúl Carrillo-Esper ${ }^{1 *}$, Ricardo Cabello-Aguilera², Juan A. Díaz Ponce-Medrano ${ }^{3}$ and \\ Dulce Ma. Carrillo-Córdova ${ }^{4}$ \\ ${ }^{1}$ Cirugía y Cirujanos Chief Editor, Academia Nacional de Medicina, Academia Mexicana de Cirugía, Instituto Nacional de Rehabilitación Luis \\ Guillermo Ibarra Ibarra; ${ }^{2}$ Hospital HMG Coyoacán; ${ }^{3}$ Hospital General Naval de Alta Especialidad; ${ }^{4}$ nstituto Nacional de Ciencias Médicas y Nutrición \\ Salvador Zubirán. Mexico City, Mexico
}

\begin{abstract}
Miguel de Cervantes Saavedra was the son of an itinerant surgeon. He wrote a masterpiece of the world literature, El Ingenioso Hidalgo Don Quijote de la Mancha. It is rivalled only by the Bible for the number of languages into which it has been translated. This masterpiece of the world literature is considered to be the first modern novel. For the physician, a reading of the Quijote is likely to veer in a medical direction. Various medical matters arise in the course of the novel, ranging from medical illness, treatments and battle wounds to the psychological profile of their characters. Cervantes's excellent nosological ability is evident when he describes symptoms and signs of illness, derived from being a witness to his father's medical practice and reading medical books. Don Quixote representing an idealized and fictional world with clear psychotic features. Although Cervantes wrote it four centuries ago, Don Quixote contains plenty of references to different specialties of medicine, and many of the ideas and concepts reflected in it are still of interest. The aim of this paper is to describe briefly the medical environment that surrounded Cervantes and its impact on the Quixote.
\end{abstract}

Key words: Cervantes, Don Quixote. Medicine.

\section{Resumen}

Miguel de Cervantes Saavedra fue hijo de un cirujano itinerante. Escribió una de las obras maestras de la literatura universal, El Ingenioso Hidalgo Don Quijote de la Mancha, considerada la primera novela moderna y solo la Biblia la rivaliza por el número de traducciones a diferentes lenguas e idiomas. La lectura del Quijote por un médico le hace dar un viraje a nuestra profesión. En sus páginas se tratan diversos y variados aspectos médicos, que van desde la descripción de diferentes enfermedades, tratamientos y heridas de batalla, al perfil psicológico de sus personajes. La capacidad de Cervantes para la descripción de hechos médicos y enfermedades es notoria, derivada de la osbservación de la actividad de su padre y de la lectura de libros de medicina. Don Quijote representa un mundo idealizado, ficticio y con claro comportamiento psicótico. A pesar de haber sido escrito hace cuatro siglos, El Quijote está lleno de referencias a diferentes especialidades de la medicina cuyo contenido sigue siendo de interés. El objetivo de este trabajo es describir brevemente el entorno médico que vivió Cervantes y su impacto en El Quijote.

Palabras clave: Cervantes. Don Quijote. Medicina.

\footnotetext{
Correspondence:

*Raúl Carrillo-Esper

Col. Arenal de Guadalupe, Del. Tlalpan Date of reception: 05-02-2018

C.P. 14389, Ciudad de México, México Date of acceptance: 23-03-2018

E-mail: revistacma@comexane.org

DOI: $10.24875 / C I R U E . M 18000088$

Cir Cir. 2018;86(6):702-711

Contents available at PubMed

www.cirugiaycirujanos.com

0009-7411/@ 2018 Academia Mexicana de Cirugía. Published by Permanyer. This is an open access article under the terms of the CC BY-NC-ND license (http://creativecommons.org/licenses/by-nc-nd/4.0/).
} 
There are no madmen anymore, my friend, there are no madmen

That Manchegan passed away

That eccentric ghost of the desert

And not even in Spain are there madmen

The entire world is sane

Terribly, hideously sane

\section{León Felipe}

"In a village of La Mancha, the name of which I have no desire to recall ..." Thus begins one of the great texts engendered by human mind, born from the pen of Miguel de Cervantes Saavedra. Don Quixote is considered the first modern novel. Cervantes was born in Alcalá de Henares on September 29, 1547, and died in Madrid on April 22, 1616. Contemporary of William Shakespeare, he lived in difficult times, in a Spain under the reign of Charles V and Philip II. A Spain that, despite its vast dominions and riches, was always avid for more and more gold and silver from its colonies of America to maintain a sumptuous court, a complex and inefficient bureaucracy, and a huge army and navy complex, continually engaged in wars and territorial conflicts. In an ultraconservative Spain, clinging to its traditions, against change, openness and enlightenment, cradle of the counter-reform, of the search for cleanliness of blood and leader on the defense of the Catholic faith. In a Spain whose people lived in fear and under suspicion, and the Inquisition was in charge of maintaining order. In a Spain where a few enjoyed the great wealth coming from its domains, and people lived with uneasiness and hunger. It was not easy for many, including Cervantes, but in such a world, our honoree wrote masterpieces of the Spanish language, which include, to our very particular understanding, one of the best works of literature written by a human being: The Ingenious Gentleman Don Quixote of La Mancha. For the entire Spanishspeaking world, the year 2016 was important because it was 400 years since the death of the "Prince of Wits", of our one-handed man of Lepanto, and I say "our" because we all have inherited something of his work, especially the wonderful language we speak: Spanish (Figs. 1 and 2).

Cervantes' literary production, although not as vast as that of other writers, is unique terms of style, composition, content and teachings. The skillful use of language and imagination are extraordinary. Don Quixote, in particular, is the living reflection of his experiences as a man, of the difficult moments he

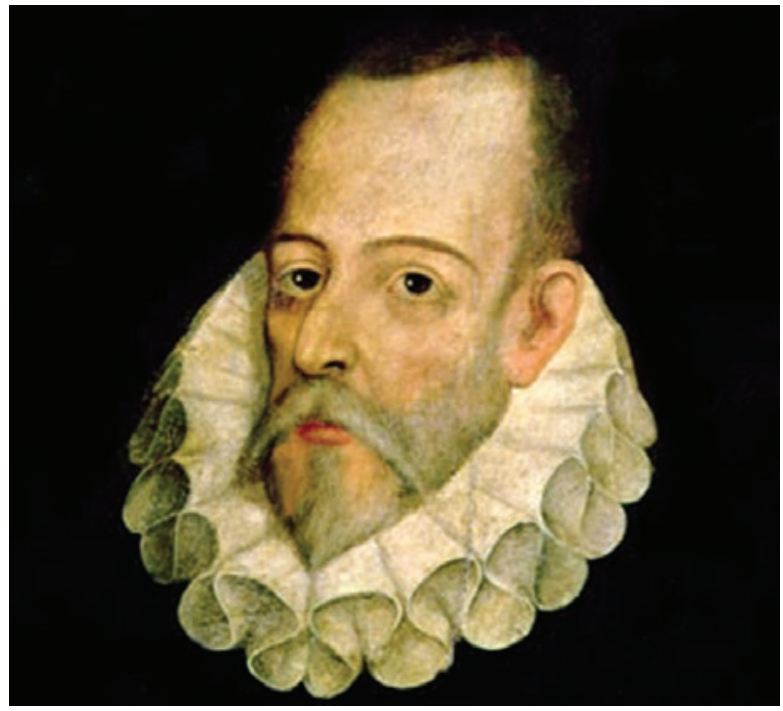

Figure 1. Don Miguel de Cervantes Saavedra, "the Prince of Wits".

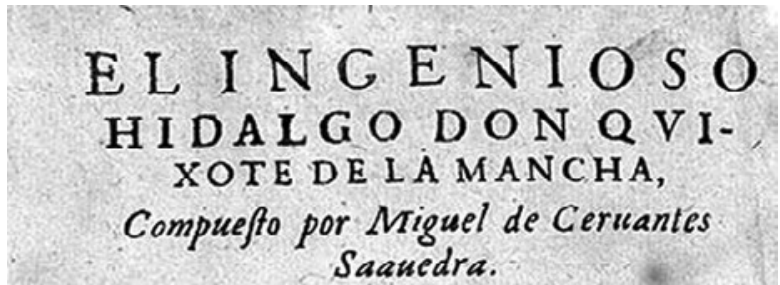

DIR I G DOAL DVQVE DE B E A R, Marques de Gibraleon, Conde de Benalcaçar, y Bañares, Vizconde de la Puebla de Alcozer, Señor de las villas de Capilla, Curiel,y Burguillos.

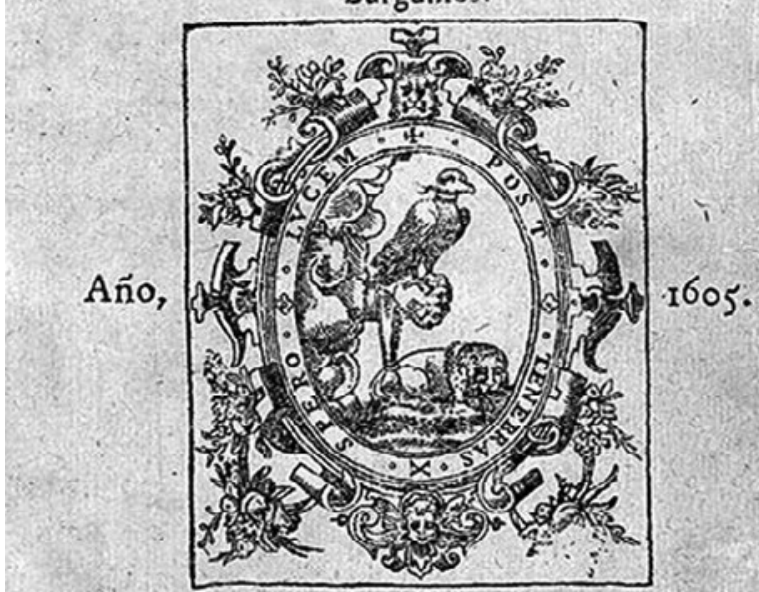

GON PR I V I L E I O, $E N \mathscr{A} \perp D I D$ Por Iuan de la Cuefta.

vondefe en eafadefrancilco de Robles, librero del Rey nío feñor.

Figure 2. Cover of one of the greatest works of human genius.

experienced as a soldier (wounded in the battle of Lepanto, hence the nickname of "the one-handed man of Lepanto"), captive of the Turk, tax collector, 
employee of a court and a decadent government, in constant struggle with a good number of enemies he made in his life, and sometimes Cervantes himself was his own enemy when he felt unable to compete in the literary field with Lope de Vega, Luis de Góngora and Quevedo (who ridiculed him with the nickname "patacoja", alluding to the lameness he suffered). By irony of life, these great figures of the Spanish Golden Age lived in the same neighborhood, then known as "de las Huertas" and currently as "de las Letras" or "de las Musas". At each phase of his life he interacted with all kinds of women and men, from whom he learned the complexity of human behavior, conduct and condition, which are experiences that had an influence on his work. Don Quixote is the crucible where a whole life melts, where Miguel de Cervantes becomes one with Alonso Quijano and Don Quixote of La Mancha.

Don Quixote is complex, it is more than an excellent literary work, than a book of chivalric romances, than a picaresque work; it is the initiation of modern novel, which represents the change that was developing not only in Spain, but also in Europe, which was living a complex time of transition between the Middle Ages and the Renaissance, when the first steps towards enlightenment and rationalism were taking place. The Cervantes who wrote Don Quixote is not the same that wrote La Galatea, Exemplary tales, Journey to Parnassus, Numancia, Trato de Argel or Los Trabajos de Persiles y Segismunda; is an informed and avid reader Cervantes, who from study, acquired knowledge and experience, imprisoned begets his great work, which reflects his maturity as a writer, intertwining literature with science based on his imagination. Although he does not cite many of the sources he consulted, it is clear that Cervantes was influenced by previous writings and that not everything was his imagination, which he offers a glimpse of in Persiles y Segismunda, where he writes: "... because lessons in books many times make the experience of things more certain, which those who have seen them lack of, because he who reads carefully notices one and many times the subject he is reading, and that who looks without care does not notice anything, and thereby he misses the lesson at sight"1.

\section{Miguel de Cervantes, his medical and humanistic surroundings}

Miguel de Cervantes, Alonso Quijano and Don Quixote have a lot in common, but for the purposes of this tribute, the authors will make a brief account of the close bond our characters had with medicine, doctors and the diseases they suffered and were tormented by.

Our multi-quoted characters lived in an era where doctors and medicine were exclusively within the reach of wealthy classes and urban areas, while the rural and the low-income population was cared for by healers or barber surgeons, based on bloodletting, purges, hot cloths and remedies that were rather magical than scientific. In the centuries between which Cervantes lived, $16^{\text {th }}$ and $17^{\text {th }}$, superstition, magical thinking, Hippocratic and Scholastic-Galenic medicine, of strong medieval roots, still dominated, but fortunately, in the Spain of those centuries, despite ideological closed-mindedness, a new renewing enlightening current was initiating in sciences, and especially in medicine, characterized by the search of critical and rational knowledge, which laid the foundations for the transition to a philosophical (scientific) and humanist medicine, a movement in which a good number of characters took part, out of which Miguel Sabuco, Francisco Sánchez and Francisco Díaz are worth mentioning, among the many who stood out in those times.

Miguel Sabuco, a Spanish naturalist, physician and apothecary, published in 1587 a text that he signed with the name of his daughter Oliva Sabuco (follower of Erasmus and considered co-author of the book), which he titled New Philosophy of the Nature of Man, not known or reached by the great ancient philosophers, which improves life and human health. In this work, in two of his colloquies or treaties, he disserts about True Medicine and True philosophy, occult to the ancients, which despite still having Galenic influence, opened the doors to a new medical-philosophical current ${ }^{2}$.

Cervantes contemporary and clear representative of this renovating movement was doctor and philosopher Francisco Sánchez, who received the nickname of "the skeptical". He was born in Tui, Pontevedra, and later he lived in Portugal and settled permanently in France. He graduated as a physician in Montpellier in 1573 and was a professor of medicine at Toulouse, a university that hosted Miguel Servet and Giordano Bruno. Francisco Sánchez laid the foundations for the scientific method, getting ahead and being a precursor of Cartesianism: "I am certain that I am writing this, I am thinking now...". His rational thinking, relativistic, guided by the senses and with a strong Pyrrhonian foundation, invites to doubt the argument of authority (previous 
knowledge), to experiment to obtain the truth, to methodical doubt and not to be forced to swear on the word of any teacher, without a doubt a strong blow to dogmatic professors. Such concepts are reflected in his works, out of which Carmen de Cometa anni M.D. LXXVII (methodical criticism of superstitious astrology) and Opera Medica stand out, but especially his magnum opus entitled Quod nihil scitur, which in his translation means "That nothing is known", where he writes: "It is innate to man wanting to know, a few were granted knowing to want; fewer, knowing. And I had no different luck than the others" and "I despair trying to find the truth, but I persist". Francisco Sánchez, along with other humanist doctors from European Renaissance, decisively contributed to take the step to the renewal of medicine, gradually leaving behind the medicine of his time, with great medieval and scholastic-Galenic influence, and opening the doors to science, putting behind common, superstitious and fraudulent practices that dominated in the Europe of the $16^{\text {th }}$ and $17^{\text {th }}$ centuries, and that fell in the fertile soil of ignorance and dominant poverty, which, according to González de Amezúa were practiced by countless tricksters, with "astrologists, astromancers, vulgar conjurers, pessimists, dark necromancers, sibylline fortune tellers, treasure finders, manufacturers of calendars, spellers, matchmaker sorceresses, healers and witches ..." standing out ${ }^{3}$ (Fig. 3).

Francisco Díaz was born in Alcalá de Henares in 1527. He studied at the University of Alcalá, where he graduated as a Doctor of Medicine in 1555. In addition to medicine, he studied philosophy, graduating in 1556. During his career as a doctor, he was in contact with distinguished practitioners of those days, among which Francisco Vallés, Fernando Mena, Pedro Jimeno and Luis Collado stand out. He was a disciple of Andrew Vesalio, from whom he learned anatomy and dissection techniques, and whom years later he replaced as Philip II doctor. Francisco Díaz is considered the father of urology, and his knowledge appears in a great work titled Newly Printed Treaty for all Diseases of the Kidneys, Bladder and Fleshy Protuberances of the Penis and Urine, divided in three books. In addition to medicine and philosophy, Francisco Díaz was interested in literature and poetry. For this reason, and due to the proximity of their families, Dr. Diaz had a great friendship with Miguel de Cervantes, which grew closer due to the fact that Dr. Diaz contributed to pay his ransom and that he was his personal doctor, since the "prince of wits" suffered, among other diseases, from kidney stones. According to Rubio Esteban, Cervantes

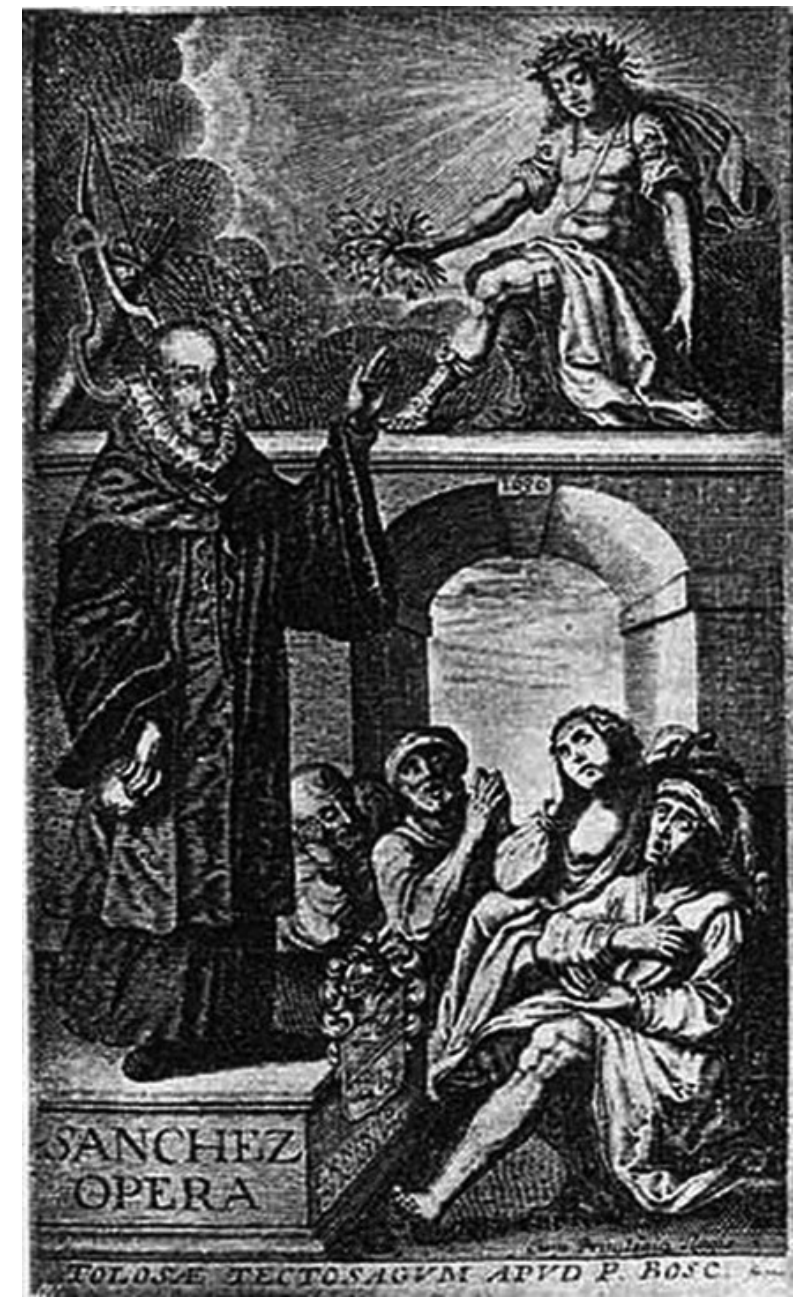

Figure 3. Dr. Francisco Sánchez, "the skeptic", illuminated by wisdom.

suffered in 1587 from a terrible nephritic colic that endangered his life, a condition for which Dr. Diaz "made him drink large amounts of water, whereby he knew how to cure the ailment of such a distinguished personality". Miguel de Cervantes' kidney disease is captured and highlighted in Don Quixote, where different related quotes appear. The close ties of friendship, the good doctor-patient relationship and Cervantes' gratitude to Dr. Francisco Díaz are evident in the following sonnet written in La Galatea ${ }^{4}$ (Fig. 4):

From you, Doctor Francisco Diaz, I can

Ensure these my Shepherds

That with confident and cheerful heart,

They can get ahead in your praises.

And if this matter short now I fall,

With your ingenuity being owed the elders,

It is because time is short, and I don't dare

Being able to pay you what I owe to you 


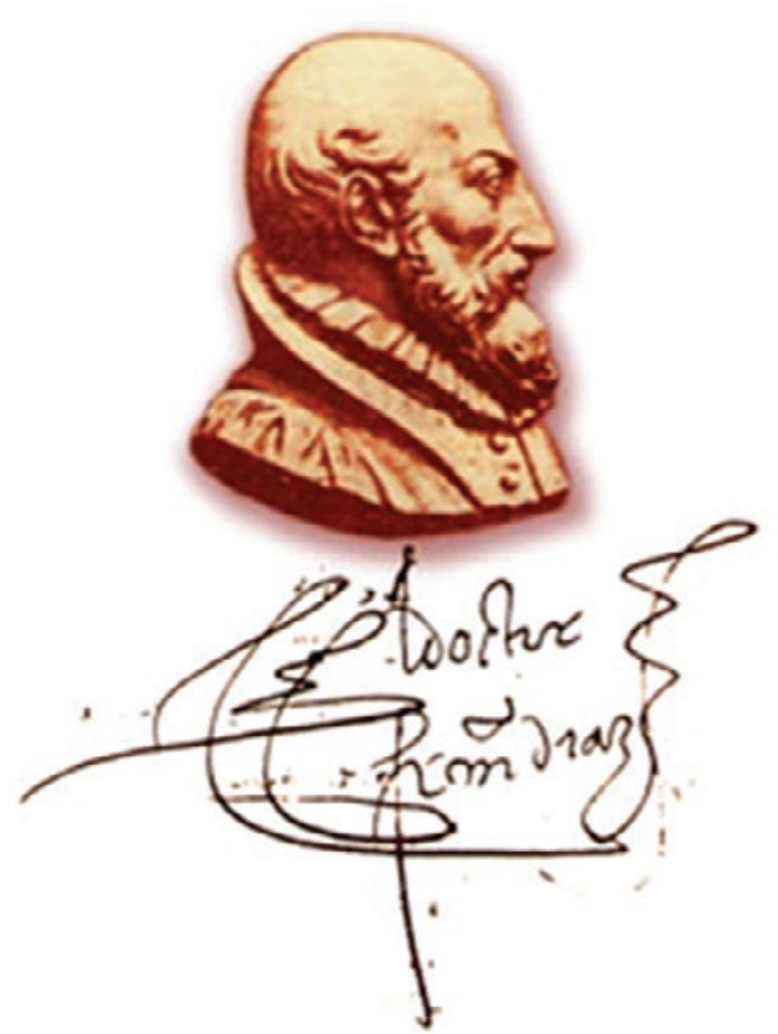

Figure 4. Dr. Francisco Díaz, Miguel de Cervantes' friend and doctor, considered the father of urology.

Thus was Cervantes' time, of recalcitrant fanaticism, inquisitorial, changing, difficult, reactionary, backward, suffocating, conflicting, in search for the truth, of persecution, of extremes, of innovation, of transition and search both in arts and in science, and especially, to what this writing concerns, in medicine. Amidst this scientific and humanist avalanche, Philip II closemindedness prevents, in 1559, the departure of Spanish doctors to study abroad.

\section{Miguel de Cervantes and the books of medicine}

In Alcalá de Henares, the house where Miguel de Cervantes was born (current Cervantes Birthplace Museum) was located in the main street, next to Hospital de Antezana, also called Hospital de Nuestra Señora de la Misericordia, founded in 1483 thanks to the charity and contributions of Don Luis de Antezana and his wife Doña Isabel de Guzmán. Juan de Cervantes, his grandfather served in that hospital.

Since childhood, Miguel de Cervantes was in contact with medicine and economic narrowness. He was the son of a has-been surgeon, Rodrigo de Cervantes, who traveled itinerantly following the court to get a job. As a barber-surgeon, he never came to graduate as Bachelor of Medicine, and thus, Cervantes' father belonged to the lowest step of the medical hierarchy of those days, since he lacked college education and his job only allowed him to practice elementary procedures such as bloodletting, suture, reduction of fractures and sprains, a work that was shared with barbers. The other type of doctors of those days were the so-called "de pulso", who had formal education and therefore more presence, clientele and income. His maternal grandfather, Juan Luis de Torreblanca, outstanding Cordovan doctor, was also the father of Mrs. Leonor de Torreblanca, mother of the "prince of wits".

Despite his efforts, Dr. Rodrigo Cervantes did not get financial slack, which led him to jail for debt in 1552 and to the embargo of its diminished assets, including his books, with the fact that his library was composed of two volumes of surgery and one grammar book standing out ${ }^{5}$.

An important fact to consider in Cervantes' life is his genealogy. Due to his doctor grandfather and his surgeon father, it has been speculated that Cervantes had a Jewish-convert origin, a controversy that continues to date, supported by some and rejected by other distinguished Cervantes esperts. In this regard, it is important mentioning that, in those days, nine out of ten doctors had this ancestry, like Andrés Laguna and Francisco López de Villalobos ${ }^{6}$. Next, we will offer a brief account of these personalities who were contemporary to Cervantes.

Andrés Laguna was a renown Spanish physician, naturalist and humanist of Jewish-convert ancestry, Cervantes' contemporary and Charles V court doctor. $\mathrm{He}$ was an avid reader of the magnum opus of Dioscorides, a Roman physician, entitled Of Medical Matters, first book where pharmacological knowledge and history of the pharmacopoeia were compiled, and which he made the first translation into Spanish of.

Contemporary to Laguna was also physician and naturalist Nicolás Monardes, countryman of Miguel de Cervantes, having both been born in Alcalá de Henares. Unlike Laguna, he was an old Christian, but just as him, he was interested in botany and medical issues. In Spain, he grew a good number of medicinal plants brought from New Spain. Laguna restricted to translating Dioscorides book and adding some annotations and illustrations to it. Monardes, instead, wrote a treaty of great importance in his time, entitled 
Medicinal History of the Things that are brought from our West Indies, where he describes the properties of many American plants, with the blessed thistle, sassafras and the guayaco stick, among others, standing out. For his contributions, Nicolás Monardes has been considered the father of pharmacology.

Francisco López de Villalobos, of Jewish-convert origin, was physician of the courts of the Catholic Monarchs, of the Duke of Alba and Charles V, whom he cared for on his final days. He described in different letters the diseases of "the Great Ones", as he called the members of the court, and the difficult relationship with them, especially for his Jewish origin (a typical case of homophobia). To give a clearer idea of what he had to endure to make a living, he had to tolerate insults like "God's parricide" and "cruelest enemy of the faithful", which at the time were serious accusations. His peers in the court of Philip II, whom he called "miserable and fools", accused him of witchcraft: "magician, connoisseur of filters and hexes". Of course, he was persecuted by the Inquisition and imprisoned. He lived several stages of his life with economic narrowness. His medical skills, his ability to become camouflaged with his environment and his resilience kept him afloat. Of his medical works Treaty on pestiferous buboes and Summary of the Medicine stand out; in the latter, he makes a synthesis of Avicenna's Canon in verse ${ }^{7,8}$.

Jewish-convert or not, Cervantes was in close contact with a medicine that was being transformed and with doctors who were making this change. Some authors have speculated that the "prince of wits" might have been a doctor, a fact forcefully rejected by great Cervantes experts. What is true, is that he had medical knowledge, and that with the profits of some of his works he put together a library that came to have 214 volumes, among which important medical works were included, with the following standing out:

- Practica in Arte Chirugica Copiosa, from Italian Giovanni da Vigo, a treatise on surgery summarized in nine books, in which anatomy, treatment of ulcers, abscesses (phlegmons), wounds, fractures, dislocations and large vessel wounds are addressed. $\mathrm{He}$ is one of the first surgeons to develop the issue of wounds caused by firearms; according to Da Vigo, in addition of the bullet, the wound was poisoned by gunpowder, and thus he recommended its treatment with boiling oil, with the purpose to counteract the poison, which was refuted years later by Ambrosio Paré, proposing different approaches. As a footnote, it is important mentioning that Da Vigo was one of the first doctors to use mercurial compounds for the treatment of syphilis 9 .

- Treatise of the Four Court Diseases, from Spaniard Luis Lobera de Ávila, court doctor and Charles $\mathrm{V}$ physician. In this book, the author wrote about syphilis or buboes disease, gout, rheumatism (sciatica) and kidney stones. Its reading could have clarified to Cervantes things related to these diseases. In addition to this book, Lobera wrote in other texts things related to dietetics and the art of good living, where the regimen noble knights should follow since they get up until they go to bed at night is emphasized and which is excellently described in Banquet of the Noble Knights, where among other things he writes on the properties of the "imperial beverage", beer, which was introduced in Spain by Charles $V^{10}$.

- Practice and Theory of Surgery, written by Spanish doctor Dionisio Daza Chacón. Little is known about this doctor, who excelled as a skilled surgeon. As relevant facts of his life, we know that he was Philip II physician and good friend of Andreas Vesalius, who surely influenced his works on surgery. His book addresses different aspects of surgery, and it is particularly meticulous in issues concerning the treatment of wounds and tumors. Regarding wounds, he describes to the perfection and with luxury of details four phases on their approach: cleaning, correction of breaks in continuity based on suture, preservation of "stitches", and the fourth and last, preventing accidents from occurring in the healing process, such as pain, inflammation, "temperature", pruritus or blood flow diversion ${ }^{11}$.

- Dioscorides, translated by Andrés Laguna, and which is mentioned in Don Quixote. From this book, Cervantes may have taken reference notes for the descriptions he makes in Don Quixote about cures based on herb cooking and infusions, which can be reflected on the Fierabrás Balm, wonderful and magical potion capable of curing all ailments of the human body, which we will offer a more extensive description of in another article, since it well deserves it.

- The treatise of all Diseases of the Kidneys..., surely presented by his doctor and friend Francisco Díaz.

- Examination of Ingenuities for Sciences, by Juan de Huarte de San Juan, on which Cervantes was inspired to write Don Quixote and from which he 
took several ideas to describe his characters, especially their peculiar personalities and psychological characteristics. Some Cervantes specialists think that the title of Cervantes' magnum opus, The Ingenious Gentleman..., was inspired by Examination of Ingenuities..., hence the "ingenious" reference. Some experts considered that this book had great influence on Cervantes. Dr. Huarte de San Juan was born in San Juan del Pie del Puerto in 1529 and graduated as a doctor of medicine maybe at the University of Alcalá de Henares, although there is no documentation of this fact. Perhaps a convert Jew, he was considered in his time as a cultured and humanistic doctor, well versed in classic authors, in the Holy Scriptures and in the Hippocratic-Galenic tradition. Examination of Ingenuities was born in Juan Bautista de Montoy Press on February 23, 1575; this editio princeps (first edition) was financed by the author himself and dedicated to Philip II. By 1584, the book was punished by the Inquisition and was included the catalog of forbidden writings in Spain and Portugal for stating that the rational soul lies in the brain and the questioning of free will, and for this reason, in a second edition, Huarte modified the text. Currently, it is considered to be one of the 10 most influential books of the Renaissance.

Exceptional for its time, since it offers a method to assess intelligence, laying the foundation of differential psychology, it emphasizes the importance of empirical observation and breaks up with Aristotelian philosophy: "It is an awfully big shame that nature has given me eyes to see and understanding to understand and to ask Aristotle and the other philosophers what shapes and colors things have and what being and nature are. Open your eyes, Plato says, and take advantage of your ingenuity and skills and don't be cowards". As a doctor, he was an excellent observer, since he described different types of personality and their relationship with madness, stating that "mental operations cannot be carried out without the brain", and organ to which the author attributed, according to its composition, determined by the four universal elements, the task of the operations of understanding. He called original talents "ingenuities", convinced that they were fundamental for intellectual work, which we currently refer to with the concept of creativity or creative intelligence. Based on the determinism of natural elements, he considered three types of intelligences, which he associated with corporeal temperaments. This way, heat determined imaginative intelligence,

\section{E X A M N \\ D $\mathbf{E}$ \\ I N G E N I O S P A R A \\ IAS SCIENCIAS.
Donde fe mueftra la diferencia de habi- lidades, queay enlos hombres; y el ge- nere de letras, que a cada vno refponde en particular.

\section{Compmefo por el Dotar I VA N H V ARTE, netimal de Sant Iman del pie del Puerto.}

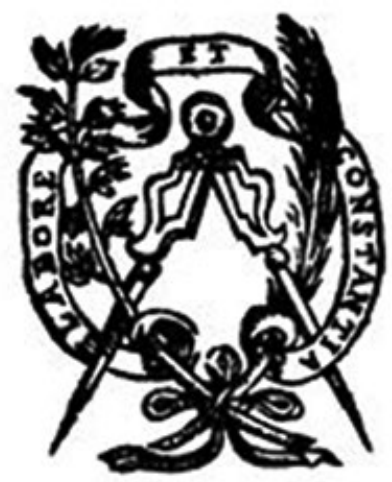

\section{Enla oficina P LANTINIANA. \\ M. DC. 11 .}

Figure 5. Cover of Examination of Ingenuities for Sciences, written by Juan de Huarte de San Juan, a text of great influence in Cervantes.

humidity was related to memory, and dryness to understanding; the latter in charge of abstract and rational thought. This way, he summed up the three faculties or powers of intelligence, of ingenuity: understanding, memory and imagination. Genius lies in originality and inventive, and hence Alonso Quijano and of Don Quixote of La Mancha's profile ${ }^{12-14}$ (Fig. 5).

Cervantes was not a physician-writer, but a writer with medical knowledge, which he got from his family and the books he surely read and consulted, enriched by his own ailments and experiences, with all this being reflected in the stories and medical facts that we find widely referred throughout Don Quixote. 


\section{Medical facts in Don Quixote}

To understand Don Quixote, we must understand Cervantes' mind and go back to the time he lived and wrote in, the $16^{\text {th }}$ century; otherwise it is difficult understanding his work, especially issues related to medical facts suffered by different characters described in his novel. It should be remembered that that was a century of transition in science, especially in medicine. In Don Quixote, diseases, symptoms, signs, cures and remedies, are intertwined, which Cervantes combined with the tradition of chivalry and scientific reality that prevailed in those days. Due to space limitations, we will restrict ourselves to making brief annotations concerning only some medical facts of Don Quixote. In this regard, it is important sharing with you who that, according to Dr. Pedro García Barreno, surgery specialist, member of the Royal Spanish Academy of Medicine and expert in Cervantes and Don Quixote, after a detailed review, in Don Quixote there are 281 medical terms that are repeated 4226 times; quite a search!15

The central character, Don Quixote of La Mancha, or Alonso Quijano, has been the reason for rivers of ink in relation to his psychiatric typology. Cervantes moves his character between the reality of a lucid character who is an avid reader and that of a lunatic, who lives insane and dies sane: "... he became so absorbed in his books that he spent his nights from sunset to sunrise, and his days from dawn to dark, poring over them; and what with little sleep and much reading his brains got so dry that he lost his wits...", "... he hit upon the strangest notion that ever madman in this world hit upon....' Does reading drive someone crazy? or do long sleepless nights do it? Such a question is not answered throughout the text, but what it can be stated is that from chivalry books he obtained teachings and a moral conscience that drove him to restore justice and help those in need, whether it was a lady in distress or a helpless widow: "Indeed, his wits being quite gone, he hit upon the strangest notion that ever madman in this world hit upon, and that was that he fancied it was right and requisite, as well for the support of his own honor as for the service of his country, that he should make a knight-errant of himself, roaming the world over in full armor and on horseback in quest of adventures, and putting in practice himself all that he had read of as being the usual practices of knights-errant; righting every kind of wrong, and exposing himself to peril and danger from which, in the issue, he was to reap eternal renown and fame..." "wrongs he intended to right, grievances to redress,

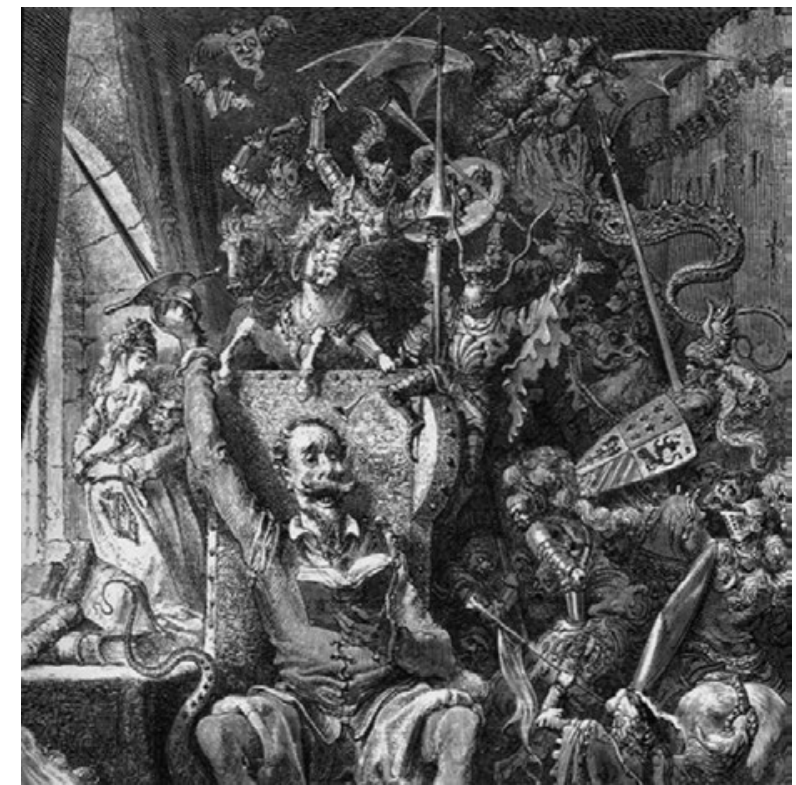

Figure 6. Don Quixote, or rather Alonso Quijano, reading. Illustration by Gustav Doré.

injustices to repair, abuses to remove, and duties to discharge...." That is madness, or enlightenment, amidst the social change that was brewing. Don Quixote represents the essence of the social leader, of the transformer that fights against the obscurantist forces and social breakdown of his time, but the sociopolitical model prevailing at the time cataloged it as a madman. His family and close acquaintances, highly worried about his behavior, did everything possible to bring him back to the myopia of sanity, to the meekness of the lambs. He lives intensely the most noble ideal of love for his muse, his lady, Dulcinea: "You don't know that knights-errant commend themselves to their ladies"; words he reprimands Sancho which. Don Quixote lives a utopian world that goes from reality to fiction, where redemption based on noblesse obligue becomes his reason for being. Alonso Quijano lives a sad and mediocre reality that is redeemed, a two-dimensionality that is experienced to this day. Who is crazier? Miguel de Cervantes, Don Quixote or Alonso Quijano? Possibly all three share some of that madness. Each character could go through the couch of a psychoanalyst. It is said that Sigmund Freud learned Spanish in order to be able to read Don Quixote in its original language and acknowledged that its reading influenced in some sense on the development of his psychoanalytic theory ${ }^{16}$ (Fig. 6).

Psychiatry scholars do not think so romantically and have diagnosed, or rather accused our gentleman of suffering, among others, reactive psychosis, bipolar 
disorder, erotic delirium syndrome (due to his special infatuation for Dulcinea), megalomania and depression, and of having a delusional interpretation of reality (persistent belief that does not correspond to reality). Without a doubt, in our time, he would have been committed and subjected to an intensive pharmacological psychiatric treatment. Opinions have gone to such an extreme, that Francisco Alonso Fernández is categorical in stating that Don Quixote is a psychopathological novel whose main character is a mental case. At the end of the novel, Don Quixote magically heals, without having received any type of treatment. Did the fever he suffered have anything to do, or was that brief improvement that precedes death? Back to sanity, he cries out "What happened to me?" and "I was mad, now I am in my senses; I was Don Quixote of La Mancha and I am now, as I said, Alonso Quijano the Good", to soon after die $e^{15,17}$.

Miguel de Cervantes is blended with Alonso Quijano (or maybe Quezada or Quijada); both were declining noblemen and getting on in years, we could say old, for a time when average life expectancy was 20 to 30 years. Cervantes, or rather Quijano, was "of a hardy habit, spare, gaunt-featured, a very early riser, of little sleep, legs skinny and hairy, dry and yellow face, wide and spacious veins". According to the theory of humors, Alonso Quijano fitted in the choleric temperament. However, due to the influence of Huarte's text, he can be classified between melancholic and choleric: "It is inferred that subjects who are melancholic by adustion combine great understanding with much imagination, but all lack memory due to a lot of dryness and hardness that caused adustion in the brain... Men who are melancholic by adustion are various and uneven in complexion, because choleric adust temperament is highly uneven...". The great influence of Examination of Ingenuities can be clearly inferred in the description of the protagonist's temperament: "In them, sometimes does vice and sometimes does virtue overcome; but in all these faults, they are the most ingenious and skillful for the ministry of preaching, and for all the things of prudence there are in the world, because they have understanding to reach the truth, and big imagination to know how to persuade it..."15.

Many medical topics and concepts appear in Don Quixote. Among them, the most commonly named word is "blood"; there is blood everywhere, bleeding and hemorrhages of all types. Various types of trauma appear constantly: fractures, dislocations, wounds, lashes, blows, falls, bites, thrashings, kicks, bruising, loss of teeth and molars, thrusts, etc., many of these

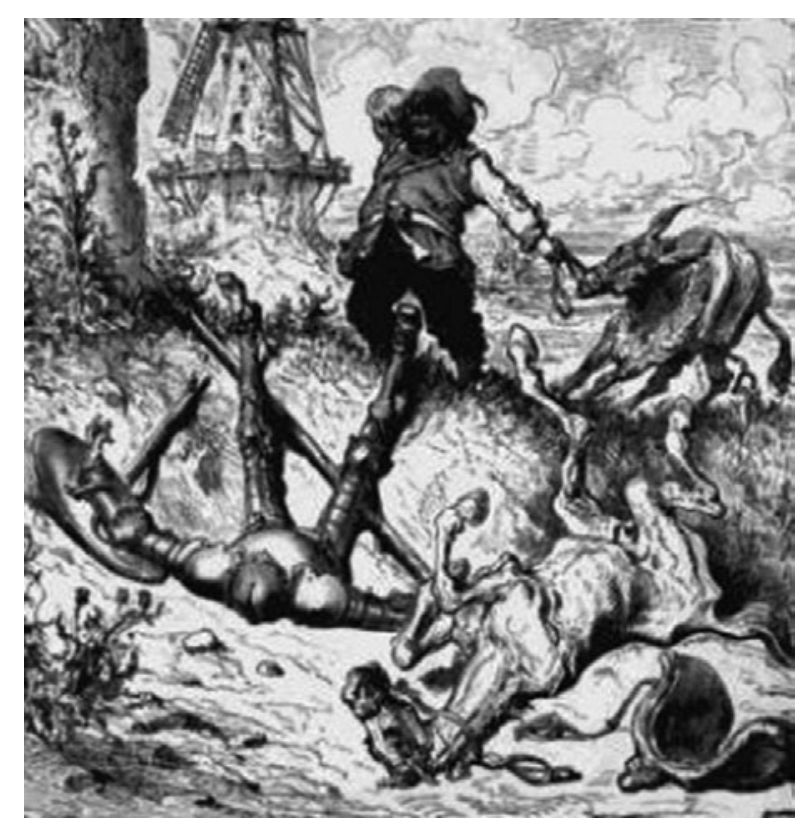

Figure 7. The fall of Don Quixote when confronting the windmills.

suffered in own flesh by the "Knight of the Rueful Countenance" and by his loyal friend and squire Sancho Panza: "He charged with such fury and fierceness that, if luck had not contrived that Rocinante should stumble midway and come down, it would have gone hard with the rash trader. Down went Rocinante, and over went his master, rolling along the ground for some distance; (...) One of the muleteers in attendance,... coming up to him seized his lance, and having broken it in pieces, with one of them he began so to belabor our Don Quixote that,... he milled him like a measure of wheat....". Throughout the story, our brave knight-errant suffered several falls, but it is the last that foreshadows the end of the noble gentleman: "Let them be, my friend; this insult is the penalty of my sin; and it is the righteous chastisement that jackals should devour a vanquished knight, and wasps sting him and pigs trample him under foot". One of the best-known falls is the one suffered by Don Quixote when charging against the windmills ${ }^{15}$ (Fig. 7).

Pain, inherent to trauma, is frequently mentioned in the text, suffered and endured in their own flesh by a good number of characters, especially the main protagonists. The subjectivity of pain intensity is evident in Don Quixote. The noble gentleman's response to pain is as follows: "And if I make no complaint of pain, it is because knights-errant are not permitted to complain of any wound, even though their bowels be coming out through it..."; in spite that it is clear that the 
pain he felt could be intense: "which caused him so much pain, that he believed, either that his hand was being cut or his arm pulled out...". Instead, good Sancho doesn't worry a lot to say what he feels, especially after suffering some bruising: "For my part, I confess I must complain however small the ache may be..." 15 .

Various ailments and their manifestations are addressed, with toothache, gingivitis, different types of inflammation or displacement of humors, vomiting, dropsy, quicksilver (mercury) poisoning, maternal death, intoxication, hirsutism, rhinophyma, tremors, syphilis, gout, asthma, plague, leprosy and various skin diseases, measles, smallpox, weakness of limbs, epilepsy, prostatic disease, kidney stones, nevi, strabismus, pestilent fever (sepsis), leprosy, cold, deformities, psychiatric and neurological diseases (cataloging the patients who suffered them as demoniac or possessed) and cataracts standing out, of which our character suffers from: "... the malign enchanter that persecutes me has brought clouds and cataracts on my eyes...". The list of diseases is long, but just mentioning them gives an idea of Cervantes' medical knowledge and his masterful ability to narrate it in his novel. The medical or therapeutic matter is not left out of Don Quixote, since the knight-errant has to be both a doctor and a herbalist. Dioscorides has a strong influence on the previously mentioned remedies, among which bloodletting, poultices, plasters, ointments, rhubarb, crystals, laxatives, enemas, oils and bandages stand out, without forgetting or neglecting the Fierabras Balm. Cervantes makes fun of many of these ineffective and sometimes dangerous remedies. Cervantes, or rather Don Quixote, couldn't forget about dietetics, since diet is a fundamental part of life, and if vegetables are eaten, better: "Dine sparingly and sup more sparingly still...", "...veal, which is better than beef, or kid, which is better than goat...". In one of the passages, he masterfully describes pica: "I suffer from an ailment which is usual in some women"18-23.

The life of every human being, even of the great ones, sooner or later comes to an end, as writings also do. Miguel de Cervantes, Alonso Quijano and Don Quixote of La Mancha were no exception. About the death of these characters, dear readers, we will give account in another writing.

\section{Conclusion}

Medicine was present in Cervantes' life and in his work, especially in Don Quixote. In this brilliant novel he displays his erudition and medical knowledge derived from reading important medicine books of his time and personal experiences. With mastery, he combines medical knowledge of the time with literature and seizes the opportunity to, with some irony, criticize doctors and their methods. His influence over the years has marked a large number of human beings, writers, artists, humanists, philosophers and scientists. It is said that Thomas Sydenham, considered the English Hippocrates, used to recommend Don Quixote as a reading to his students. And doctor and poet Richard Blackmore used to say: "If you want to learn medicine, read Don Quixote; it is a very interesting book, I read it quite often...".

\section{References}

1. Biblioteca virtual Miguel de Cervantes. Disponible en: www.cervantesvirtual.com.

2. Ruiz FJ. La Nueva Filosofía de Oliva y Miguel Sabuco. Rev Fac Educ Albacete. 2012;27:121-41.

3. Orden-Jiménez RV. Francisco Sánchez, el Escéptico. Breve historia de un filósofo desenfocado. Departamento de Historia y Filosofía. Universidad Complutense de Madrid. Madrid: Fundación Ignacio Larramendi; 2012. Disponible en: www.larramendi.es/francisco_sanchez/i18n/cms/fichero.cmd?id=ms/francisco_sanchez/ficheros/fsanchez_estudio_fundacionlarreamend.pdf.

4. Carrillo ER, Carrillo Córdova LD, Carrillo Córdova DM, Carrillo Córdova CA, Carrillo Córdova JR. Andrés Vesalio, Francisco Díaz, Miguel de Cervantes Saavedra y el nacimiento de la urología en el siglo XVI. Gac Med Mex. 2015;15:543-52.

5. Fernández de Cano JP. Rodrigo de Cervantes 1509-1585. Disponible en: www.mcnbiografias.com/app-bio/do/show?key=cervantes-rodrigo-de.

6. Gómez Menor-Fuentes J. La oscura genealogía de Cervantes. Disponible en: htpp://biblioteca2.uclm.es/biblioteca/ceclm/artrevistas/Toletum/ tol33/toletum33 gomezoscura.pdf.

7. Puerto-Sarmiento FJ. Andrés Laguna. 1510-1569. Biblioteca Virtual de Polígrafo. Disponible en: www.larramendi.es/cytamerica/i18n/consulta_ aut/registro.cmd?id=3117.

8. Arrizabalaga J. Francisco López de Villalobos (1473-1549). Médico cortesano. Acta Hisp Med Sci Hist Illus. 2002;22:29-58.

9. Ring ME. Giovanni da Vigo. Surgeon and dentist of Pope. Bull Hist Dent. 1968;16:2-8.

10. Bujosa HF. Biography of Luis Lobera de Ávila. Disponible en: http:// thebiography.us/en/lobera-de-avila-luis.

11. Beltrán de Hereida y de Onis J. Dionisio Daza Chacon, cirujano del Renacimiento; su aportación al tratamiento de las heridas. Universidad de Valladolid; 1971. Disponible en: http://uvadoc.uva.es/bitstream/10324/4126/1/ Disc.Apert,UVA1971-72.pdf.

12. Gondra JM. Juan Huarte de San Juan y las diferencias de inteligencia. Anuario de Psicología. 1994;60:13-34.

13. Pinillos JL. El Examen de los Ingenios cuatro siglos después. Revista de Psicología General y Aplicada. 1976;31:3-15.

14. Bellido-Mainar JR, Sanz-Valer VP, Berrueta-Maetzu LM. Juan de Huarte de San Juan: un precursor del análisis de la actividad y de la orientación vocacional. TOG. 2012;9:1-18

15. García-Barreno PR. La medicina en El Quijote y en su entorno. Barcelona: Crítica; 2005. p. 155-79.

16. Grinberg L, Rodríguez JF. The influence of Cervantes on the future creator of psychoanalysis. Int J Psychoanal. 1984;65:155-68.

17. Rodríguez GA. Realidad, ficción y juego en el Quijote: locura-cordura. Rev Chil Lit. 2005;67:161-75.

18. Moraga-Ramos I. Salud, enfermedad y muerte en El Quijote. Actas II. Asociación Cervantistas. p. 337-52. Disponible en: https://cvc.cervantes. es/literatura/cervantistas/coloquios/cl_II/cl_II_27.pdf.

19. Sáenz-Santamaría CM, García-Latasa FJ, Gilabrete Y, Carapeto FJ. Dermatologic diseases in Don Quixote: skin conditions from Cervante's pen. Int J Dermatol. 1995;34:212-5.

20. Pinto C. Medical classics: Don Quixote. BMJ. 2007;335:997.

21. Peleg R, Tandeter H, Peleg A. The medical Cervantes. CMAJ. 2001; 165:1623-4.

22. Allegra CJ, Benedeti JK. Don Quixote and the quest for personalized medicine. J Clin Oncol. 2008;26:2619-20.

23. Palma JA, Palma F. Neurology and Don Quixote. Eur Neurol. 2012; 68:247-57. 